\section{SISTEM OBUKE SPORTISTA SA INVALIDITETOM U SPORTOVIMA SNAGE}

\author{
THE TRAINING SYSTEM OF \\ ATHLETES WITH DISABILITIES \\ IN STRENGTH SPORTS
}

\section{Mariia Roztorhui ${ }^{1}$, Alina Perederiy $^{1}$, Yuriy Briskin ${ }^{1}$ i Olexandr Tovstonoh ${ }^{1}$}

${ }^{1}$ Lviv State Univesity of Physical Culture, Lviv, Ukrajina

Originalni naučni članak doi:10.5550/sgia.181401.se.rpy UDC:796.012.11-056.26

Received: 06.04.2018. Approved: 12.06.2018.

Korespodencija: Mariia Roztorhui, Doktorski kandidat University of Physical Culture, Lviv, Ukraine mariia.roztorhyi@gmail.com

Sportlogia 2018, 14 (1), 93-101. E-ISSN 1986-6119

\title{
SAŽETAK
}

Analiza naučne $i$ metodološke literature pokazuje fragmentarnu prirodu dostupnih informacija o pitanjima sistema obuke sportista sa invaliditetom u sportovima snage. Danas se posmatra mehanički prenos neadekvatnih naučnih $i$ metodoloških pristupa pripremi sportista u olimpijskom sportu do adaptivnog sporta. Cilj istraživanja je da se identifikuju specifičnosti sastavljanja sistema treninga za sportiste sa invaliditetom u sportovima snage. $U$ istraživanju su uključeni treneri $(n=54)$ koji rade na snazi u sportu. Upitnik je proveden $u$ otvorenom obliku na osnovu 15 regionalnih centara fizičke kulture i sporta za invalide "Invasport". Na osnovu analize rezultata upitnika razvijena je teorijska struktura dugoročne višegodišnje pripreme sportista sa invaliditetom u sportovima snage. Pored toga, utvrđeni su preporučeni kvantitativni pokazatelji konkurentnih aktivnosti sportista u sportovima snage. Utvrđeno je da struktura dugoročne višegodišnje pripreme treba da sadrži pet faza, čije trajanje zavisi od nivoa ostatnih motoričkih sposobnosti sportista. Otkrivena je neophodnost korekcije pristupa za sastavljanje sistema obuke za sportiste sa invaliditetom u sportovima snage na osnovu prilagođavanja odgovarajućih pristupa opšte teorije osobenosti treninga sportista sa invaliditetom.

Ključne reči: dugoročna višegodišnja priprema, struktura, adaptivni sportovi 


\section{INTRODUCTION}

The effectiveness of training system of people with disabilities in strength sports is determined by a number of factors. Important among them are the correctness of approaches to scientific and methodological support of their preparation, taking into account the level of saved motor abilities and peculiarities of motor activity (Bolach \& Prystupa, 2014; DePauw, \& Gavron, 1995; Winnick \& Porretta, 2017).

Modern scientific research on training of athletes with disabilities in strength sports is based on scientific and methodological works devoted to certain aspects of training athletes with musculoskeletal system damage in powerlifting as a Paralympic kind of sports (Prystypa, Stefaniak \& Rudenko, 2017). In particular, the authors have investigated the impact of powerlifting on the body of athletes with disabilities (Biankina \& Khomichenko, 2015), historical aspects of powerlifting development for people with disabilities (Stecenko, 2013), improvement of physical, technical and mental fitness of athletes with disabilities in musculoskeletal system (Prystypa, Stefaniak \& Rudenko, 2017) and consideration of nosological features of strength lifters with disabilities in musculoskeletal system in the training process (Ilmatov, 2015). The problem of training athletes of other nosological groups in powerlifting and arm-wrestling was studied by authors in terms of identifying the effectiveness of arm-wrestling for the socialization of people with disabilities (Kharitonashvili, Comaia \& Budzishvili, 2007) and powerlifting for improving physical fitness of athletes with visual impairment (Gromov, 2006).

The fragmentary nature of the available scientific research makes it impossible to operate an effective scientific and methodological support for the training of athletes with disabilities in strength sports. Therefore, in the practice of sports, the training of athletes with disabilities is predominantly characterized by a mechanical transfer of approaches of general theory of athletes' training to the training of athletes with disabilities in strength sports (Fishe, McNelis, Gorgey, Dolbow \& Goetz, 2015; Prystypa, Stefaniak \& Rudenko, 2017). It may lead to reduction of sport longevity and possibility of realizing sports potential of people with disabilities in the process of achieving the maximum possible result (Sakakibara, Shin, Watanabe, \& Matsuoka, 2014; Gee, West, \& Krassioukov, 2015; Chatzilelecas, Filipović, \& Petrinović, 2015; Fidler, Schmidt \& Vauhnik 2017).

An analysis of the scientific and methodological base of adaptive sport points to a number of problems. In particular, the system of training athletes with disabilities is not adapted to the regularities of the development of sports skills in strength sports and the specifics of their saved motor abilities. Thus, the formation of scientific knowledge about the structure and content of multi-year preparation of athletes with disabilities in strength sports is becoming relevant.

The aim of research is to identify the peculiarities of composing a training system for athletes with disabilities in strength sports.

\section{METHODS}

The following methods were used in this research: bibliographic study of theoreticalconceptual, methodological and practical outlines presented in specialized scientificmethodical literature; study of documentary materials; method of inquiry, questionnaire; expert evaluation methods; method of mathematical statistics. In preparing the research we used conceptual approaches to working out scientific research questionnaires in physical education and sports (Ashmarin, 1978).

In the research were invited 54 coaches, among them: the Honored Coaches of Ukraine $(n=13)$, coaches of the highest category $(n=10)$, coaches of the first category $(n=16)$, coaches of the second category $(n=10)$, coaches without category $(n=5)$. It had been continuing from September 2017 to December 2017. Among the respondents, 31 coaches

Roztorhui, M., Perederiy, A., Briskin, Y., \& Tovstonoh, O. (2018). Sistem obuke sportista sa invaliditetom u sportovima snage. Sportlogia, 14 (1), 93-101. doi:10.1550/sgia.181401.se.rpy 
work in Regional Centers of Physical Culture and Sports for the Disabled "Invasport" and 23 coaches work on a voluntary basis with athletes with disabilities. The average work experience of respondents in the field of strength sports for the disabled was $9,44 \pm 6,01$ years, and their average age $-39,49 \pm 9,54$ years. All respondents gave permission to disclose information about their participation in the research.

The questionnaire included section on demographic information about respondents (age, work experience, qualifications, kind of sport) and the main part, which included 8 openended questions, 3 questions regarding the ranking of response criteria and 2 close-ended questions. Open-ended questions related to the definition of quantitative indices on different issues of training system for athletes with disabilities in strength sports (number of training sessions, number of hours in one microcycle, number of competitions, percentage ratios of different types of training).

The arithmetic mean $(\mathrm{X})$ and the standard deviation $(\sigma)$ were calculated to determine the average demographic information of the respondents and the answers to questions, where numbers were involved. There was calculated Kendall's coefficient of concordance (W) for the questions that provided the answer in the form of indices ranking for significance. The purpose of this was to evaluate the extent of the agreement among raters in relation to the ranking of response criteria. The statistical processing of the research materials was conducted using the Microsoft Excel 2010 software package and the Statistica 6.0 software.

\section{RESULTS}

The analysis of respondents' answers to the question about the methodological basis for composing training system of athletes with disabilities shows that $81,48 \%$ of respondents use syllabus for healthy athletes in their practice. At the same time, 90,74\% of respondents indicated that while training athletes with disabilities, they primarily guided by their own experience, because there are no training programs of athletes with disabilities in strength sports. Only $44,44 \%$ of respondents are familiar with foreign programs for people with disabilities.

According to expert's opinion in the field of strength sports for the disabled (96,29\% of respondents), the structure of long-term multiannual preparation of athletes with disabilities should differ from those accepted in the general theory of training of athletes. Among respondences $98,14 \%$ consider that the length of stages of training system depends on the level of remained motor abilities of athletes.

Results of answers on the question allowed us to form the theoretical model of long-term multiannual preparation of athletes with disabilities in strength sports, which includes five main stages shown in Figure 1. 


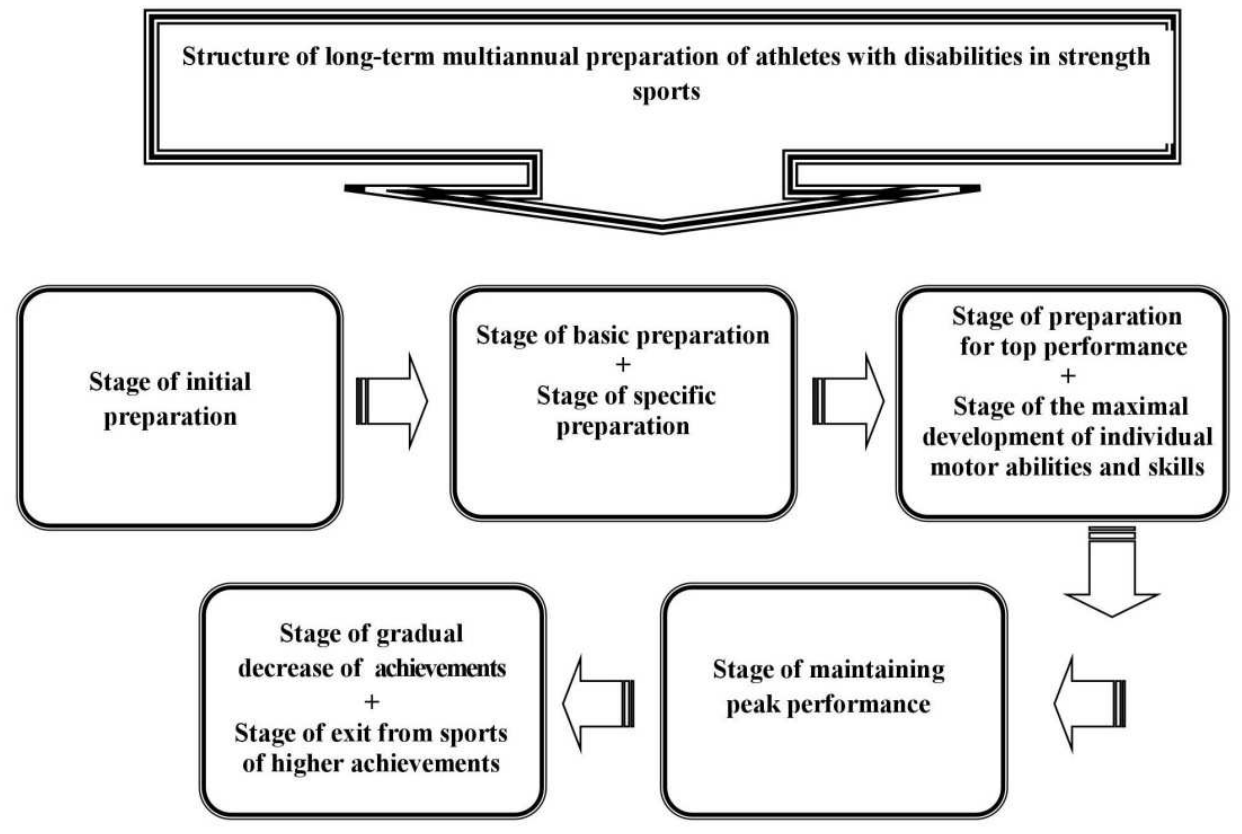

Figure 1. Theoretical model of the structure of long-term multiannual preparation of athletes with disabilities in strength sports.

In the structure of long-term multiannual preparation of athletes with disabilities in strength sports, it is necessary to single out the stages of initial preparation (100, 00\% of respondents) and stages of maintaining peak performance (98,15\% of respondents). Percentage indices about the allocation of other stages in the structure of long-term multiannual preparation for athletes with disabilities were less than the statistical majority.

Respondents indicated the need to combine some of the stages in different ways. According to $70,37 \%$ of respondents, in the structure of long-term multiannual preparation of athletes in strength sports there is a need for scientific and methodological substantiation of a new stage of preparation. The purpose and tasks of it will be deciding the declared goal and tasks of the stage of gradual decrease of achievements and exit from sports of higher achievements. In opinion of $55,56 \%$ respondents the stages of basic preparation and specific preparation need to be combined into a single stage in long-term multiannual preparation of athletes with disabilities. At the same time $53,70 \%$ of respondents believe that the stages of preparation for top performance and the maximal development of individual motor abilities and skills need to be reformatted into a single stage, which will solve the common tasks of preparation of both stages.

Respondents also determined the quantitative indices of competitive and training activities of athletes with disabilities of different qualifications in strength sports, which are described in Table 1. 
Table 1. Recommended quantitative indices of competitive and training activities of athletes with disabilities of different qualifications in strength sports

\begin{tabular}{ccccccc}
\hline $\begin{array}{c}\text { Qualification of } \\
\text { athletes }\end{array}$ & \multicolumn{2}{c}{$\begin{array}{c}\text { Number of } \\
\text { competitions in } \\
\text { annual training } \\
\text { cycle }\end{array}$} & \multicolumn{2}{c}{$\begin{array}{c}\text { Number of training } \\
\text { sessions in a weekly } \\
\text { microcycle }\end{array}$} & $\begin{array}{c}\text { Number of hours of } \\
\text { training sessions in a } \\
\text { weekly microcycle }\end{array}$ \\
\hline Junior grades & 2,41 & $\pm 0,69$ & 3,28 & $\pm 0,76$ & 7,07 & $\pm 1,71$ \\
$\begin{array}{c}\text { III sporting } \\
\text { grade }\end{array}$ & 3,17 & $\pm 0,67$ & 4,20 & $\pm 0,74$ & 8,41 & $\pm 1,46$ \\
$\begin{array}{c}\text { II sporting } \\
\text { grade }\end{array}$ & 3,98 & $\pm 0,69$ & 4,76 & $\pm 0,85$ & 11,19 & $\pm 2,19$ \\
$\begin{array}{c}\text { I sporting } \\
\text { grade }\end{array}$ & 4,63 & $\pm 0,77$ & 5,74 & $\pm 0,81$ & 14,54 & $\pm 2,62$ \\
$\begin{array}{c}\text { Candidate for } \\
\text { Master of Sport }\end{array}$ & 5,54 & $\pm 0,72$ & 6,83 & $\pm 1,16$ & 19,26 & $\pm 2,67$ \\
$\begin{array}{c}\text { Master of Sport } \\
\text { Master of Sport } \\
\text { International } \\
\text { Class }\end{array}$ & 6,46 & $\pm 0,70$ & 8,33 & $\pm 1,27$ & 24,35 & $\pm 2,83$ \\
Merited Master of \\
Sport
\end{tabular}

Legend: $\mathrm{X}$ - average mean; $\sigma$ - standard deviation.

During the realization of research, we found that, according to the opinions of respondents, the most important criterion is the fulfillment of the requirements for the assignment of sports grades and titles. At the same time, the level of consistency of opinion of respondents in all cases was satisfactory (coefficient of concordance $(\mathrm{W}=0,698-0,764)$.

When determining the significance of the criteria for the transfer of athletes with disabilities from junior grades to the next training group, the first place with a sum of 198 and an average grade of 3,67 (standard deviation, $\mathrm{SD}=0,52$ ) respondents gave to special transfer tests from the kind of sport. The next criterion of significance is the scales for assessing the motor abilities of athletes with disabilities with a sum of 165 and an average grade of 3,06 $(\mathrm{SD}=0,42)$. The criterion for fulfilling the requirements for the assignment of sports grades and titles was ranked third (rank sum was 103, average rank 1,91, SD =0,70). The criterion duration of training of athletes, according to respondents, is the least significant when determining readiness for transfer of athletes with disabilities to the next group of training (the sum of ranks was 64 , the average rank $1,19, \mathrm{SD}=0,40$ ). The value coefficient of concordance was 0,606 , which suggests satisfactory consistency of opinion of respondents.

\section{DISCUSSION}

The assumptions concerning the mechanical transfer of approaches of general theory of athletes' training to the training of athletes with disabilities has been confirmed. This statement is found in the works of a number of authors, which studied the characteristics of the training of athletes in adaptive sports (Herasymenko, Mukhin, Pityn \& Kozibroda, 2016; Cruz \& Blauwet, 2018). The obtained results also confirm the necessity of taking into account the level of remained motor abilities when composing training system of athletes with disabilities, which was declared by other authors (Biankina \& Khomichenko, 2015; Prystypa, Stefaniak \& Rudenko, 2017).

Roztorhui, M., Perederiy, A., Briskin, Y., \& Tovstonoh, O. (2018). Sistem obuke sportista sa invaliditetom u sportovima snage. Sportlogia, 14 (1), 93-101. doi:10.1550/sgia.181401.se.rpy 
For the first time was developed a theoretical model of the structure of training system for athletes in adaptive sports. The respondents identified five main stages in the structure of longterm multiannual preparation of athletes with disabilities. Some respondents proposed the allocation of a new stage, which is different from the stages declared in the general theory of training of athletes - a rehabilitation stage. Among of the interviewed coaches 33,33\% indicated in the rationale for the structure of long-term multiannual preparation of athletes with disabilities that the modern system of long-term multiannual preparation for this athletes needs the allocation of a rehabilitation stage as a separate structural element. The percentages for the allocation of this stage are lower than the statistical majority. Simultaneously a qualitative analysis of the level of professional qualification of respondents who insist on the allocation of this stage, allow us to put forward some hypothesis. It refers to the need for additional researches on the rehabilitation stage as a separate structural element of long-term multiannual preparation of athletes with disabilities in strength sports. Among the respondents who indicated the need for the rehabilitation stage were 11 Honored Coaches of Ukraine, 3 coaches of the highest category and 4 coaches of the first category. This determines the need to take into account the opinion of these coaches in the process of scientific and methodological substantiation of long-term multiannual preparation. In researches of some authors there are attempts to substantiate this stage as an integral part of the structure of long-term multiannual preparation of athletes with injuries in the musculoskeletal system (Briskin, Evseev \& Perederiy, 2010; Biankina \& Khomichenko, 2015).

As the result of analysis of respondents' answers, for the first time has defined recommended number of competitions in annual training cycle, in which athletes with disabilities of different qualifications in strength sports should participate. In addition, the available information was supplemented with quantitative indices of training sessions in a weekly microcycle for athletes with disabilities of different qualifications in strength sports. Comparative analysis of the obtained indices number of hours of training sessions in a weekly microcycle for athletes with disabilities and the norms of the weekly regimen of training for people with disabilities in children's and youth sports schools, indicates the need of correction weekly training session norms for athletes with disabilities. Besides, the norms, which were approved by the normative documents of the weekly training work for athletes with disabilities coincide with these norms for healthy athletes. It reflects the negative tendency for the mechanical transfer of organizational and methodological approaches for preparation of athletes in the Olympic sport to the preparation of athletes with disabilities.

One of the results of research, which was found out for the first time, is the definition by respondents the importance of criteria for determining the readiness of athletes with disabilities of different qualifications specializing in strength sports for transfer to the next training group. According to the opinions expressed, the most significant for athletes of the youth grades are special transfer sports tests for the assessment of special preparedness. Equally important are the scales for assessing of remained motor abilities of athletes with disabilities. At the same time, the criterion of fulfilling the requirements for the assignment of sports grades and titles according to the Uniform Sport Classification, which respondents identified as the most significant for skilled and highly skilled athletes with disabilities, was ranked only third in the rankings for athletes of junior grades. As in strength sports, sports result directly depends on the level of remained motor abilities of athletes, athletes with severe forms of lesions cannot fully realize their sporting potential. This suggests the need for using special transfer tests and scales of assessment of saved motor abilities in order to assess the readiness of athletes for transfer to the next training group. And also it is confirming the need for a significant correction of approaches to the training of athletes with disabilities in strength sport.

Roztorhui, M., Perederiy, A., Briskin, Y., \& Tovstonoh, O. (2018). Sistem obuke sportista sa invaliditetom u sportovima snage. Sportlogia, 14 (1), 93-101. doi:10.1550/sgia.181401.se.rpy 


\section{CONCLUSIONS}

It has been established that the structure of long-term multiannual preparation for athletes with disabilities should be different from the structure of long-term multiannual preparation for athletes in the Olympic sport. And also should be adapted to the needs of the practice of strength kinds of adaptive sports.

The theoretical model of structure of long-term multiannual preparation of athletes with disabilities was developed. There were determined recommended quantitative indices of competitive and training activities for athletes with disabilities of different qualifications in strength sports.

\section{LITERATURA}

Ashmarin, B. A. (1978). Theory and methods of pedagogical studies in physical education. Moscow: Fizicheskaya kultura.

Biankina, L. V., \& Khomichenko, A. V. (2015). Problems of defining stages of training for strengthlifters with musculoskeletal injuries. Uchenye zapiski universiteta imeni P. F. Lesgafta, 10(128), 33-36.

Bolach, B., \& Prystupa, T. (2014). Evaluation of perception of quality of life of disabled athletes. Physical education of students, 1, 13-16. https://doi.org/10.6084/m9.figshare.903687

Briskin, I. A., Evseev, S. P., \& Perederiy, A. V. (2010). Adaptive sport. Moscow: Sovetskiy sport.

Chatzilelecas, E., Filipović, B., \& Petrinović, L. (2015). Differences in quality of life according to the level of ohysical activity between two groups of basketball in the wheelchairs. SportLogia,11(1), 11-17.

https://doi.org/10.5550/sgia.151101.en.008C

Cruz, S., \& Blauwet, C. A. (2018). Implications of altered autonomic control on sports performance in athletes with spinal cord injury. Autonomic Neuroscience: Basic andClinical.Retrieved

from https://www.researchgate.net/publication/315946581_Implications_of_altered_ autonomic_control_on_sports_performance_in_athletes_with_spinal_cord_inju ry. https://doi.org/10.1016/j.autneu.2017.03.006

DePauw, K. P., \& Gavron, S. J. (1995). Disability and sport. Champaing: Human Kinetics.

Fidler, A., Schmidt, M., \& Vauhnik, J. (2017). Ways that people with a chronic spinal cord injury participate in sport in the Republic of Slovenia. Journal of Physical Education and Sport, 17(3), 1892-1898. https://doi.org/10.7752/jpes.2017.03184

Fishe, J. A., McNelis, M. A., Gorgey, A. S., Dolbow, D. R., \& Goetz, L. L. (2015). Does Upper Extremity Training Influence Body Composition after Spinal Cord Injury? Aging and Disease, 6(4), 271-281. https://doi.org/10.14336/AD.2014.0912

Gee, C. M., West, C. R., \& Krassioukov, A. V. (2015). Boosting in elite athletes with spinal cord injury: a critical review of physiology and testing procedures. Sports Medicine, 45, 1133-1142. https://doi.org/10.1007/s40279-015-0340-9

Gromov, V. A. (2006). Methodology of training for people with visual impairement in powerlifting and its influence on coordination of movements. ( $\mathrm{PhD}$ dissertation). Russian State University of Physical Education, Sport, Youth and Tourism, Moscow. Retrieved from http://www.dissercat.com/content/metodika-

Roztorhui, M., Perederiy, A., Briskin, Y., \& Tovstonoh, O. (2018). Sistem obuke sportista sa invaliditetom u sportovima snage. Sportlogia, 14 (1), 93-101. doi:10.1550/sgia.181401.se.rpy 
trenirovki-v-pauerliftinge-slabovidyashchikh-lyudei-i-ee-vliyanie-nakoordinatsiyu-.

Herasymenko, O., Mukhin, V., Pityn, M., \& Kozibroda, L. (2016). Shift of physical activity index for individuals with lower limb amputations as influenced by the comprehensive program of physical rehabilitation. Journal of physical education and sport, 16(1), 707-712.

https://doi.org/10.7752/jpes.2016.s1115

Ilmatov, V. R. (2015). Research of the functional state of the musculoskeletal system of young strengthlifters with vertebrogenic leisons of the spine. Pedagogics psychology medical-biological problems of physical training and sports, 10, 3338.

http://dx.doi. org/10.15561/18189172.2015.1005

Kharitonashvili, K., Comaia, A., \& Budzishvili, N. (2007). Ways to improve mass character of sports specialization of athletes with disabilities in armwrestling. Pedagogics psychology medical-biological problems of physical training and sports, 5, 233-235.

Prystypa, T., Stefaniak, T., \& Rudenko, R. (2017). Impact of athletic recovery parameters of hemodynamics in disabled strengthlifters with cerebral palsy. Pedagogics, psychology, medical-biological problems of physical training and sports, 21(3), 131-138.

https://doi.org/10.15561/18189172.2017.0306

Sakakibara, N., Shin, S., Watanabe, T., \& Matsuoka, T. (2014). Influence of lumbopelvic stability on deadlift performance in competitive strengthlifters. SportLogia,10 (2), 89-95. https://doi.org/10.5550/sgia.141002.en.005S

Stecenko, A. I. (2013). Peculiarities of the development of powerlifting in the system of adaptive sports. Adaptivnaia fizicheskaia kul'tura, 4, 10-13.

Winnick, J., \& Porretta, D. (2017). Adapted Physical Education and Sport (6th ed.). Champaing: Human Kinetics.

\section{SUMMARY}

The analysis of scientific and methodological literature shows the fragmentary nature of the available information on the issues of training system for athletes with disabilities in strength sports. The mechanical transfer of unadapt scientific and methodological approaches to the preparation of athletes in the Olympic sport to adaptive sports is observed today. The aim of the research is to identify the peculiarities of composing a training system for athletes with disabilities in strength sports. We involved coaches $(n=54)$ working in the field of strength sports in the research. The questionnaire was conducted in an open form on the basis of 15 Regional Centers of Physical Culture and Sports for the Disabled "Invasport". Based on the analysis of questionnaire results, the theoretical structure of long-term multiannual preparation of athletes with disabilities in strength sports was developed. In addition, we have determined the recommended quantitative indices of competitive and training activities for athletes in strength sports. It was established that the structure of longterm multiannual preparation should include five stages, the duration of which depends on the level of remained motor abilities of athletes. The necessity of approaches correction is revealed for composing training system for athletes with disabilities in strength sports on the

Roztorhui, M., Perederiy, A., Briskin, Y., \& Tovstonoh, O. (2018). Sistem obuke sportista sa invaliditetom u sportovima snage. Sportlogia, 14 (1), 93-101. doi:10.1550/sgia.181401.se.rpy 
basis of adaptation of the corresponding approaches of general theory to the peculiarities of training athletes with disabilities.

Key words: long-term multiannual preparation, structure, adaptive sports.

\section{ПОДГОТОВКА СПОРТСМЕНОВ С ИНВАЛИДНОСТЬЮ В СИЛОВЫХ ВИДАХ СПОРТАХ}

\section{РЕЗЮМЕ}

Анализ научно-методической литературы свидетельствует о фрагментарном характере имеющегося научного знания по проблематике подготовки спортсменов с инвалидностью в силовых видах спорта. Сегодня наблюдается механическое перенесение неадаптированных научно-методических подходов к подготовке спортсменов в олимпийском спорте в адаптивный спорт. Целью исследования является выявление особенностей построения подготовки спортсменов с инвалидностью в силовых видах спорта. Исследование проводилось с привлечением тренеров $(\mathrm{n}=54)$, которые работают в области силовых видов спорта. Анкетирование было проведено в открытой форме на базе 15 региональных центров физической культуры и спорта инвалидов «Инваспорт». На основе анализа полученных результатов разработана теоретическая структура многолетней подготовки спортсменов с инвалидностью в силовых видах спорта, определены рекомендованные количественные показатели соревновательной и тренировочной деятельности спортсменов с инвалидностью в силовых видах спорта. Установлено, что структура многолетней подготовки спортсменов должна включать пять этапов, продолжительность которых зависит от уровня сохранившихся двигательных возможностей спортсменов. Выявлена необходимость в коррекции подходов к построению многолетней подготовки спортсменов с инвалидностью в силовых видах спорта на основе адаптации положений общей теории подготовки спортсменов к специфике подготовки спортсменов с инвалидностью.

Ключевые слова: многолетняя подготовка, структура, адаптивный спорт.

Primljeno: 06.04.2018. Odobreno: 12.06.2018.

Korespodencija: Mariia Roztorhui, Doktorski kandidat, Lviv State University of Physical Culture, Lviv, Ukraine mariia.roztorhyi@gmail.com

Roztorhui, M., Perederiy, A., Briskin, Y., \& Tovstonoh, O. (2018). Sistem obuke sportista sa invaliditetom u sportovima snage. Sportlogia, 14 (1), 93-101. doi:10.1550/sgia.181401.se.rpy 